\title{
Fedotova Hanna,
}

Doctor of Juridical Sciences, Senior

Research Associate, Head of the

Department, State Research Institute

MIA Ukraine, Kyiv, Ukraine

ORCID ID 0000-0002-7798-3143

\section{Anastasiia Burbii,}

Postgraduate, Leading legal adviser,

State Research Institute MIA Ukraine,

Kyiv, Ukraine

ORCID ID 0000-0003-4866-321X

\section{ESTABLISHING AND DEVELOPING CRIMINAL LIABILITY FOR CRIMES AGAINST VOTING RIGHTS}

The study analyzes the historical stages of development of the institution of electoral rights. Attention is paid to such historical and legal phenomenon as viche (people's assembly) - historical form of decision of many public affairs in Kyivska Rus. Based on historical documents, proved that during the period of Kievan Rus its sights, although not directly used the words "elections", " electoral law", did not disclose their content, still forming an idea about the electoral rights and making the first regulatory attempts to protect them. The stage of Polish-Lithuanian period, when Ukrainian lands were part of neighboring countries, was analyzed separately. According to the Sudebnik (Lawyer) 1497, the instigators of the riots - "kramolniki" - were defined as "swindlers" and "robbers".

According to the Cossack law, there is no separate liability for violations of the norms of election, but for minor offenses there was a restriction of certain rights, in particular, a ban on holding elective Kozak positions. And among the war crimes were such as evasion from the position on which the society chose the Kozak. It is proved 
that the legal norms, which were directly aimed at the protection of electoral rights, in the Cossack law there are no simultaneous elections during the legal system of Hetmanshchyna as the main legitimizing institution.

For the first time, criminal law provisions establishing criminal liability for acts that infringe on electoral legal relations and voting rights appeared in the Ulozhenie on penalties in 1845. A significant historical step in this period is the formation of norms concerning electoral rights and freedoms. First and foremost, these were peasant, zemstvo, urban, judicial, military and other reforms in the Russian Empire in the 6070 s of the 19th century, of which Ukraine was a part. They brought personal freedom to former serfs, as well as their legal capacity, through the lands and city councils laid the foundation for local self-government, initiated a number of democratic changes in the implementation of justice, presented the role of the individual in many areas of state and public life. Electoral rights as an institution of state law existed also in the preSoviet period, however, responsibility for their violation was established.

During the Soviet era, the penalty of "loss of rights" is defined as deprivation by the legislature of the right to vote, for a term not exceeding five years, to vote actively and passively; to vote actively and passively in professional and other organizations; to hold responsible positions; and to serve as assessors of the people's court, defense counsel, guardian or custodian.

At the time of independence, in 1993, the Criminal Code (CC) of Ukraine for the first time had a provision that protected referendum rights and legal relations (the CC was supplemented by article 129-1 "Violation of legislation on referendum"). In 1999 it was added to the Criminal Code of Ukraine for the first time. The mentioned chapter of the $\mathrm{CC}$ was named "Crimes against electoral, labor and other personal rights of a citizen".

Currently, for the purpose of codification of electoral legislation and establishment of transparent, accessible and understandable rules for all participants in the electoral process, as well as to prevent misuse of administrative resources, the impossibility of bribing members of election commissions and voters and other violations that are usually observed during elections, the Electoral Code of Ukraine was adopted. 
Keywords: elections, electoral process, criminal liability for violation of electoral rights, protection of citizens' electoral rights

\section{REFERENCES}

1. Ferri E. (1890) Prestupleniia i priestupniki v naukie i zhizni. "Crimes and criminals in science and life". Two lectures. Odessa. 54 p. [in Russian].

2. Istoriia derzhavnoi sluzhby v Ukraini: u 5 Vol. "History of the civil service in Ukraine": 5 T. / resp. ed. T.V. Motrenko, V.A. Smolii; A.M. Beha, H.V. Boriak (supervisor), L.Ya. Demchenko et al. Main Department of the Civil Service of Ukraine; National Academy of Sciences of Ukraine. Institute of History of Ukraine. K.: NikaCenter, 2009. Vol. 1. 636 p. [in Ukrainian].

3. Tereshchenko Yu.I. (1996) Ukraina i yevropeiskyi svit: Narys istorii vid utvorennia Starokyivskoi derzhavy do kintsia XVI stolittia: navch. posib. "Ukraine and the European World: An Outline of History from the Formation of the Starokyivka State to the End of the 16th Century: Tutorial. K.: Perun. 496 p. [in Ukrainian].

4. Vasiliev S.V. (2011) Pskovskaia Sudnaia hramota i I Litovskii Statut: ucheb. posobiie. "Pskov Judicial Charter and I Lithuanian Statute": textbook. M.: Kvadryha.128 p. [in Russian].

5. Ozhiohov S.I. (1983) Slovar russkoho yazyka. "Dictionary of the Russian language". / edited by N.Yu. Swiedova. 14th ed. M.: Rus. lang. 816 p. [in Russian].

6. Rossiiskoie zakonodatielstvo $\mathrm{X}-\mathrm{XX}$ vekov: $\mathrm{v} 9$ t. "Russian legislation of the tenth and twentieth centuries": in 9 volumes / under total. ed. O.I. Chistyakova. M: Jurid. lit., 1984. Vol. 2: Legislation of the period of formation and strengthening of the Russian centralized state. 519 p. [in Russian].

7. Nelin O.I. (2016) Istoriia derzhavy i prava Ukrainy: pidruch. "History of the State and Law of Ukraine": Textbook. K.: Vid-polyhraph. Center "Kyiv University". 719 p. [in Ukrainian].

8. Krasikov A.N. (2000) Uholovno-pravovaia okhrana politicheskikh, hrazhdanskikh i inykh konstitutsionnykh prav i svobod chielovieka i hrazhdanina $\mathrm{v}$ Rossii. "Criminal legal protection of political, civil and other constitutional rights and 
freedoms of man and citizen in Russia". Saratov: Publishing House of the Saratov University. 104 p. [in Russian].

9. Sbornik dokumentov po istorii uholovnoho zakonodatielstva SSSR i RSFSR, 1917-1952 hh. "Collection of documents on the history of criminal legislation of the USSR and the RSFSR, 1917-1952 / ed. Holiakova I.T. M.: State. publishing house jur. literature, 1953. 463 p. [in Russian].

10. Mikhailenko P.P. (1966) Borba s prestupnostiu v Ukrainskoi SSR. "The fight against crime in the Ukrainian SSR". K. Vol. 1.831 p. [in Russian].

11. Mikhailenko P.P. (1967) Borba s prestupnostiu v Ukrainskoi SSR. "The fight against crime in the Ukrainian SSR”. K. Vol. 2. 952 p. [in Russian].

12. Uholovnoie zakonodatelstvo Soiuza SSR i soouznykh respublik. "Criminal law of the USSR and Union Republics". M.: State. publishing house Jur. Literature, 1963.Vol. 1. 656 p. [in Russian].

13. Vyborchyi kodeks Ukrainy vid 19.12.2019 № 396-IX. “The Electoral Code of Ukraine dated 19.12.2019 No. 396-IX”. URL: https://zakon.rada.gov.ua/laws/card/396-20 (date of application: 29.09.2019) [in Ukrainian]. 